\title{
Znanost temeljena na dokazima u nefrologiji, dijalizi i transplantaciji bubrega
}

\section{Evidence-based nephrology}

\author{
Martina Pavletić Peršić, Sanjin Rački
}

\begin{abstract}
Sažetak. Nefrologija je mlada grana interne medicine čiji razvoj započinje 60-ih godina prošlog stoljeća uvođenjem nadomještanja bubrežne funkcije u svakodnevnu kliničku praksu. Nakon gotovo pola stoljeća i publiciranog velikog broja studija pokazalo se da je velik broj njih upitne kvalitete te je zaključeno da nefrološkoj struci nedostaju randomizirane studije visoke kvalitete. Učinjeno je niz akcija u suradnji i s nefrološkom Cochrane grupom s ciljem unapređenja struke te su date jasne preporuke za buduća klinička istraživanja. Nefrološka Cochrane grupa prihvatila je tri naslova naše grupe u Rijeci i u fazi smo izrade protokola o prevenciji kontrastne nefropatije.
\end{abstract}

Ključne riječi: kontrastna nefropatija; kronična bubrežna bolest; nefrologija; randomizirane kontrolirane studije.

Abstract. Nephrology is a young branch of internal medicine whose development began in the 60 s of the last century by introducing the renal replacement therapy in everyday clinical practice. After nearly half a century of publicity, it has been shown that a large number of studies are of questionable quality and it has been concluded that the nephrology lacked randomized controlled trials of high quality. A series of actions were carried out in cooperation with the renal Cochrane group with the aim of advancing the profession and giving clear recommendations for future clinical research. Our group in Rijeka has three review titles accepted in the renal Cochrane group and we have been drafting a protocol on the prevention of contrast nephropathy.

Key words: chronic kidney disease; contrast-induced nephropathy; nephrology; randomized controlled trials
Zavod za nefrologiju, dijalizu i transplantaciju, Klinički bolnički centar Rijeka, Rijeka

*Dopisni autor:

Martina Pavletić Peršić, dr. med. Zavod za nefrologiju, dijalizu i transplantaciju

Klinika za internu medicinu Klinički bolnički centar Rijeka Tome Strižića 3, 51000 Rijeka e-mail:martinapavletic@yahoo.com

http://hrcak.srce.hr/medicina 


\section{UVOD}

Nefrologija je jedna od mlađih grana interne medicine i bavi se bolestima bubrega. Sam naziv nefrologija (sastavljen od grčke riječi nephros "bubreg" i sufiksa -logy "znanost") nastao je prije samo nešto više od pola stoljeća za vrijeme kongresa "Premier Congres International de Nephrologie" koji se održavao od 1. do 4. rujna 1960. u Evianu (Francuska) i Ženevi (Švicarska), a organiziralo ga je novonastalo Međunarodno nefrološko

Prevalencija pacijenata $\mathrm{S}$ KBB-om procjenjuje se na gotovo 26 milijuna odraslih u SAD-u te oko $10 \%-18 \%$ u svijetu.

društvo (engl. International Society of Nephrolo$g y-$ ISN). Od tog vremena započinje brz i nezaustavljiv razvoj nefrološke struke i prvi počeci kliničkih studija u nefrologiji, a kao najveći motor razvoja smatra se pronalazak mogućnosti nadomještanja bubrežne funkcije dijalizom, a potom $i$ transplantacijom. U početku je dijalitičko liječenje bilo usmjereno isključivo prema pacijentima s akutnom bubrežnom ozljedom, da bi se tijekom sljedećih nekoliko godina postepeno počeli otvarati pri bolnicama centri i za izabrane kronične bubrežne pacijente. U našoj zemlji prva hemodijaliza bila je izvedena 17. lipnja 1962. godine u Rijeci, kada su u čitavoj Europi postojala tek 44 centra za dijalizu. Tek nakon dva desetljeća od prvih početaka, zaživio je širom svijeta kronični dijalitički program kakav poznajemo danas. Desetljeće nakon toga, 1981. godine publicirana je prva randomizirana kontrolirana studija o učincima hemodijalize na morbiditet pacijenata ${ }^{1}$.

Nefrologija se dijeli u deset područja, a najveće cjeline su: nefrologija u užem smislu (bavi se primarnim bolestima bubrega), akutna nefrologija (direktno ulazi u područje intenzivne medicine $\mathrm{i}$ svih drugih akutnih stanja), dijaliza (hemodijaliza $i$ peritonejska dijaliza), transplantacija i arterijska hipertenzija (preklapanje s interesima kardiologije). Unazad četrdesetak godina razvoj dijaliznih metoda i transplantacije omogućilo je razvoj nefrologije kakav imamo danas. Nažalost, zapadnjački stil života s epidemijama debljine, šećerne bolesti i arterijske hipertenzije odgovorni su za sve veći broj pacijenata s kroničnom bubrežnom bolesti (KBB) koja se filtrira u novo, veliko područje interesa unutar nefrološke struke. Prevalencija pacijenata s KBB-om procjenjuje se na gotovo 26 milijuna odraslih u Sjedinjenim Američkim Državama (SAD) te oko $10 \%-18 \%$ u svijetu ${ }^{2,3}$.

\section{ZNANOST TEMELJENA NA DOKAZIMA U NEFROLOGIJI}

Studija Lowrieja i suradnika o učincima hemodijalize na morbiditet pacijenata liječenih hemodijalizom trajala je 6 mjeseci. Sponzorirao ju je Nacionalni institut zdravlja (engl. National Institutes of Healths; $\mathrm{NIH})^{1}$. Osnovni rezultat studije koja je uključila 160 većinom mladih pacijenata bila je da veća doza dijalize smanjuje mortalitet pacijenata ${ }^{1}$. Naknadna analiza rezultata uvela je dva surogat markera praćenja doze dijalize koji se i dan danas koriste u svakodnevnoj kliničkoj prak$\mathrm{si}$, a to su Kt/V ( $\mathrm{K}$ - klirens ureje dijalizatora, $\mathrm{t}$ - vrijeme na dijalizi, $\mathrm{V}$ - tjelesni volumen distribucije ureje) $\mathrm{i}$ omjer odstranjenja ureje (URR; urea removal ratio) ${ }^{1}$. Razvoj struke i kliničkih studija pokazali su da se fokus nefrologa mora prebaciti s $10 \%$ pacijenata koji se liječe nadomještanjem bubrežne funkcije na daleko veći broj pacijenata u predijalitičkom stadiju. Uslijedile su studije određivanja ostatne bubrežne funkcije, odnosno glomerularne filtracije koje preciznije određuju preostalu bubrežnu funkciju u odnosu na određivanje veličine kreatinina kao surogat markera bubrežnog oštećenja ${ }^{4}$. Danas se procijenjena veličina glomerularne filtracije rutinski određuje izračunom i prikazuje u izdatim laboratorijskim nalazima, što je omogućilo senzibiliziranje šire medicinske javnosti na prisutno bubrežno oštećenje, odnosno kroničnu bolest i povezalo nefrologiju s drugim strukama, prvenstveno kardiologijom, endokrinologijom, imunologijom, gastroenterologijom i mnogim drugima. Nakon tog vremena dolazi do daljnjeg porasta broja randomiziranih studija, kako u cjelokupnoj medicini tako i u nefrologiji, koje nas gotovo svakodnevno preplavljuju, pa se postavlja pitanje kako in kritički sagledati. Randomizirane kontrolirane studije su u kliničkom ispitivanju zlatni standard koji nam daje odgovore o učinkovitosti, dobrobiti i poten- 
cijalnoj štetnosti ispitivanog lijeka u odnosu na standardno prihvaćeno liječenje. No, da bi randomizirana kontrolirana studija dala adekvatne odgovore (klinički važne) mora imati dobru metodologiju, dovoljan broj uključenih pacijenata i, posebno važno, u nefrologiji mjeriti učinak ispitivanog lijeka kroz prizmu za nefrologiju klinički važnih pokazatelja (renalnih - npr. povećanje incidencije potrebe dijalitičkog liječenja, produIjenje vremena do započinjanja dijalitičkog liječenja, odnosno nerenalnih - npr. kardiovaskularna smrtnost), a ne praćenje tzv. surogat markera, kao što su pad procijenjene glomerularne filtracije (eGFR) ili porast serumskog kreatinina, povećanje proteinurije i slično. Sami surogat markeri jednostavniji su za praćenje, ali nisu nužno i klinički važni ili dovoljno važni da bi pokazali učinkovitost, odnosno potencijalnu štetnost ispitivanog lijeka ili liječenja. No, svaki razvoj i traženje istine neminovno ima i određenih poteškoća, odnosno negativnih strana. Uspoređujući količinu učinjenih studija u nefrologiji s ostalim područjima interne medicine vidjet ćemo da nefroška struka na prijelazu stoljeća zaostaje po količini publiciranih randomiziranih kontroliranih kliničkih studija od ostalih područja interne medicine. Istražujući kvantitetu i kvalitetu publiciranih randomiziranih kontroliranih studija u nefrologiji, Strippoli je sa suradnicima 2004. godine pokazao da gledajući unatrag 4 desetljeća (od 1966. do 2002. godine) postoji velik porast broja objavljenih randomiziranih kliničkih studija, gdje npr. kardiologija bilježi ukupni porast od 6 puta, a samo u posljednjem desetljeću ima deset puta više publiciranih studija od nefrologije ${ }^{5}$. Ne samo da je broj studija bio daleko manji, nego je i kvaliteta studija upitna, prvenstveno zbog malog broja uključenih pacijenata i korištenja tzv. surogat markera. Nefrologija je, iako bilježi jasan porast, u cijelom vremenu praćenja od 40 godina, na posljednjem mjestu $\mathrm{s}$ ukupno publiciranih 2.779 randomiziranih kliničkih studija ( $95 \% \mathrm{Cl}, 2.677$ do 2.885 ), što sačinjava $1,15 \%$ (95 \% Cl, 1,11 do 1,20 \%) od ukupnog broja nefroloških studija u navedenom periodu ${ }^{5}$. Osim same kvantitete, autori su posebno skrenuli pažnju na upitnu kvalitetu zbog manjkavosti u metodologiji, dizajnu i netransparentnom prikazivanju randomizacije i rezultata studija ${ }^{5}$.
Nefrologiji nedostaju randomizirane studije visoke kvalitete koje bi nas vodile u svakodnevnom propisivanju terapije. Negativne posljedice njihovog nedostatka i moguće štete iskusili smo s epoetinima nakon što su tek 2007. godine nakon više od dva desetljeća njihovog korištenja randomizirane studije i njihova metaanaliza pokazale i njihove potencijalne negativne posljedice i promijenile dotadašnje smjernice ciljnog hemoglobina u pacijenata liječenih epoetinima ${ }^{6}$. Što više uspijemo kritički sagledati kvalitetu publiciranih randomiziranih studija, razumjet ćemo razinu i snagu iz njih dobivenih dokaza, te na kraju donijeti preporuke za bolje studije u budućnosti. Nekoliko je parametara kojima pratimo kvalitetu studija, od njih su najvažniji: jasna randomizacija, slijepa studija, "intention to treat" analiza i praćenje pacijenata. Deo i suradnici ispitali su tri karakteristike kvalitete u studijama publiciranim u nefrologiji 2007. i 2008. godine ${ }^{7}$. Njihovi rezultati pokazali su da je gotovo dvije trećine studija od 110 izabranih izostavljalo sudionike iz analize, od toga je više od polovice studija izostavilo više od 10 \% njih. Polovica svih studija nije učinila "intention to treat" analizu ili su prikazani rezultati i metodologija bili nejasni, a manje od $5 \%$ studija objasnilo je razloge ispalih podataka ${ }^{7}$. Nakon radova Strippolija i suradnika publicirano je nekoliko preglednih članaka koji su na različite načine kritički sagledavali stanje u nefrologiji. Inrig sa suradnicima je 2014. godine publicirala sustavni pregledni članak o kliničkim studijama u nefrologiji registriranim u ClinicalTrials.gov s ciljem da odgovori na pitanje o kvaliteti publiciranih studija u nefrologiji ${ }^{8}$. $U$ ispitivanom periodu od 2007. do 2010. godine ukupno je bilo registrirano 40,970 studija, od čega $2,6 \%$ u području nefrologije i 5,5 \% u području kardiologije. Randomiziranih je bilo nešto manje od tri četvrtine $(72,3 \%)$, intervencijskih 75,4\%, a u usporedbi s kardiološkim studijama uključivali su manji broj pacijenata (više od $50 \%$ manje od 100 pacijenata); slijepih studija bilo je svega trećina $(33,8 \%)^{8}$. Prema populaciji nefroloških pacijenata u nešto manje od trećine studija bili su pacijenti s kroničnom bubrežnom bolesti (29\%), $18 \%$ transplantirani pacijenti, dok su na trećem mjestu po učestalosti s po $8 \%$ bili pacijenti s akutnom bubrežnom ozlje- 
dom i glomerularnim bolestima ${ }^{8}$. Ubrzo je postalo jasno da od velike količine studija malo ima onih koje su dale kvalitetne rezultate koje koriste krajnjem korisniku - pacijentu. Najveće kritike bile su usmjerene na metodologiju i dizajn učinjenih studija s premalo uključenih pacijenata, netransparentnom randomizacijom, neprikazivanjem razloga ispalih pacijenata u praćenju, korištenjem tzv. surogat ishoda, neprikazivanja štetnih ishoda liječenja itd. Da bi se poboljšala ne samo znanost nego i nefrološka struka, učinjeni

Nefrologiji nedostaju randomizirane studije visoke kvalitete koje bi nas vodile u svakodnevnom propisivanju terapije.

su na međunarodnom planu veliki koraci kao preduvjeti potrebnih promjena. $S$ početkom novog stoljeća započele su se sve potrebne predradnje, od kritičkog sagledavanja stanja, koje je preduvjet za bilo kakve promjene na bolje, do konkretnih radnji koje imaju za cilj unaprjeđenje i edukaciju struke, organizaciju kvalitetnih kliničkih studija koje će nam u bliskoj budućnosti dati rezultate koji nam nedostaju. Jedna od takvih novina bila je knjiga "Evidence based nephrology" publicirana 31. prosinca 2008. godine, glavnih urednika Donalda A. Molonyja i Jonathana C. Craiga ${ }^{9}$. Knjiga je obuhvatila sva područja nefrologije, uključujući dijalizu, transplantaciju i pedijatrijsku populaciju, a bazira se na GRADE sustavu preporuka ${ }^{10-12}$. Godine 2016. u američkom nefrološkom časopisu (engl. Clinical Journal of the American Society of Nephrology), započela je serija "Nefrologija zasnovana na dokazima" (engl. EvidenceBased Nephrology), čiji je zadatak da približi čitatelju klinički važna područja u nefrologiji s naglaskom na postojeće dokaze koji podupiru trenutna znanja i preporuke za buduća istraživanja. Svaki pregledni rad u navedenoj seriji prate uvodni članci koji daju uz metodološka objašnjenja prikazanih studija (uključujući kvalitetu i slabosti studija) i kritički sažetak dokaza u određenom području nefrologije ${ }^{13}$. Prva takva serija "Nefrologije zasnovane na dokazima" bila je posvećena terapiji hipertenzije u pacijenata na kroničnoj dijali$\mathrm{zi}^{14}$. Na kraju 2016. godine, zbog velikog broja studija u proteklom razdoblju koje su iznjedrile veliku količinu podataka, ali nažalost disproporcionalno malo kvalitetnih rezultata, u međunarodnoj nefrološkoj akademskoj zajednici došlo je do velikog udruživanja s ciljem sveobuhvatne analize dosadašnjeg znanja. Rezultat navedene akcije je okupljanje vodećih svjetskih nefroloških stručnjaka na konferenciji u Parizu u rujnu 2016. godine pod naslovom: "KDIGO Controversies Conference on Challenges in the Conduct of Clinical Trials in Nephrology Conference Participants". Na konferenciji se dogovorila strategija istraživanja i postavili su se jasni ciljevi i zadatci. Nakon početnog sagledavanja stanja u kojemu se između ostaloga uočilo kako nedostaje kvalitetnih randomiziranih studija s dovoljnim brojem uključenih pacijenata, nastala je publikacija sa smjernicama kako osmisliti randomiziranu kontroliranu studiju u specifičnoj grupi nefroloških pacijenata, publicirana u kolovozu 2017. godine ${ }^{15}$. Na sastanku su se jasno i nedvosmisleno dale smjernice za buduća istraživanja, dosadašnja literatura očistila se od velikog nepotrebnog otpada koji nije dao tražene rezultate, a potrošio velike financijske resurse. Ako se navedene preporuke budu uvažavale, buduće studije trebale bi biti dovoljno velike i kvalitetne da nam daju prijeko potrebne znanstveno utemeljene dokaze za sigurno i učinkovito liječenje nefroloških pacijenata ${ }^{15}$. Navedene akcije u uskoj su suradnji i s nefrološkom Cochrane grupom.

\section{COCHRANE U NEFROLOGIJI}

U usporedbi s drugim granama medicine nefrologija je relativno mlada struka s intenzivnim razvojem posljednjih 30-ak godina. U periodu od 1990. do 2005. publicirano je preko 400 sustavnih preglednih članaka i metaanaliza, većina (40 \%) u području kronične bubrežne bolesti, dok je $15 \%$ literature $u$ istom vremenu praćenja posvećeno akutnoj bubrežnoj ozljedi ${ }^{16}$. Mnoge od tih studija daju nejednake, a često i oprečne odgovore na postavljena pitanja, što dodatno zbunjuje čitaoca. Same metaanalize ponekad je nemoguće provesti, odnosno zaključci su nesigurni radi velike heterogenosti i nejednake metodologije korištene $u$ pojedinačnim studijama. Da bismo dobili kvalitetne odgovore koji se mogu implementirati u svakodnevnu praksu potrebni su sustavni pre- 
gledni članci koji će se redovito ažurirati. Od ukupnog broja publiciranih studija do 2008. godine svega $10 \%$ randomiziranih kliničkih studija je bilo sažeto u sustavnim preglednim člancima $(1.000$ od dotad postojećih 10.000 randomiziranih kliničkih studija) ${ }^{9}$. No, da bi publicirane studije bile bliske prosječnom čitatelju - nefrologu, kao i sustavni pregledni članci, publicirano je nekoliko članaka koji se bave tematikom kako kritički sagledati kliničke studije u nefrologiji, što tražiti u metaanalizama te kako koristiti sustavne pregledne članke ${ }^{16-18}$.

\section{Primarni fokus Cochrane nefrološke i transplantacijske grupe - Cochrane Kidney and Transplant}

Sjedište Cochrane nefrološke i transplantacijske grupe nalazi se u Sydneyju, u Australiji ${ }^{19}$. Prvotno je bila osnovana 1. ožujka, 1997. godine u Lionu, u Francuskoj. U svibnju 2000. godine uredništvo se seli u Australiju. Ova grupa primarno se bavi problematikom bolesti bubrega, komplikacijama šećerne bolesti i arterijske hipertenzije. Potpuno pokrivaju i druga područja kao što su: akutno bubrežno oštećenje, kronična bubrežna bolest, dijabetična nefropatija, glomerulonefritisi, transplantacija bubrega, transplantacija solidnih organa, uroinfekcije i učinci lijekova na bubrežnu funkciju. Fokus im je pretežno na kliničkim ishodima, kao što su smrt, potreba za dijalitičkim liječenjem ili kvaliteta života, dok su neklinički ishodi npr. mjerenje glomerularne filtracije ili veličina proteinurije prihvaćeni kao sekundarni ishodi. Važnost njihovom radu daje i podrška međunarodnih nefroloških društava. Do sada je publicirano preko 200 sustavnih preglednih članaka, trenutačno je 51 protokol u izradi i ima prihvaćeno (registrirano) 27 naslova. Nefrološka Cochrane grupa ima specijalizirani registar randomiziranih kontroliranih studija iz područja nefrologije od prvih publikacija 60-ih godina prošlog stoljeća do danas. Registar se trajno nadopunjava pretraživanjem drugih baza i ručnim pretraživanjem literature na engleskom i drugim jezicima, uključujući i knjige sažetaka kongresa ${ }^{20}$. Sadrži preko 4.000 studija kojima se može pristupiti kroz nefrološku Cochrane grupu, odnosno centralnu knjižnicu Cochrane (Cochrane Central). Primjera radi, smatra se da Medline u usporedbi s ovim registrom stu- dija prikaže svega 20 - 25 \% randomiziranih kontroliranih studija iz područja nefrologije ${ }^{5}$.

\section{RIJEČKA SURADNJA S COCHRANE}

NEFROLOŠKOM I TRANSPLANTACIJSKOM

$$
\text { GRUPOM }
$$

U Rijeci je u suradnji s gastroenterolozima koji su već publicirali nekoliko Cochrane sustavnih preglednih članaka započeta nefrološka Cochrane avantura u području akutne bubrežne ozljede el-27. $^{21}$.

Nefrologija je jedna od najaktivnijih grana medicine, čiji se novi zamah razvoja očekuje u stručnom i znanstvenom području u nadolazećim godinama.

Nefrološko sjedište Cochrane u Australiji prihvatilo je tri naslova koja istražuju mogućnost prevencije kontrastne nefropatije: parenteralnom hidracijom, acetilcisteinom odnosno bikarbonatima. Trenutačno su sva tri protokola u fazi izrade, a rezultati istraživanja dat će odgovore na pitanja s čime, kada se, kako i u kojoj populaciji pacijenata može prevenirati kontrastna nefropatija. S obzirom na široku primjenu radiološkog kontrasta, kako u dijagnostičke tako i u terapijske svrhe, u sve starijoj populaciji opterećenoj brojnim komorbiditetima od presudne je važnosti prevencija mogućeg ijatrogenog oštećenja. Na navedenu temu do sada su publicirane brojne studije šarolike metodologije i heterogene skupine pacijenata. Deseci metaanaliza nisu dali nedvosmislene rezultate o tome, primjerice, prevenira li ili ne acetilcistein kontrastnu nefropatiju, ali s obzirom na to da je lijek sigurnog profila s malo nuspojava, ušao je s nivoom dokaza 2D u europske nefrološke smjernice, ali nije i u europske uroradiološke smjernice (s preporukom klase IIb, nivoom dokaza A), gdje se jasno navodi da nema kvalitetnih dokaza za preporuku korištenja u prevenciji kontrastne nefropatije ${ }^{28-33}$. Obje smjernice publicirane su u kratkom vremenskom intervalu od niti jedne godine (2011. i 2012. godine), dakle s istim dostupnim dokazima koji su sagledani na drugi način. Samo ovaj primjer govori koliko su nam potrebne kvalitetne randomizirane studije i sustavni pregledni članci koji će dati nedvosmislene 
odgovore i ukazati na područja u kojima nam nedostaju kvalitetni dokazi te dati smjernice za buduća istraživanja. Jedna takva studija od koje se puno očekuje je Studija "Prevencija velikih neželjenih događaja nakon angiografije" (engl. Prevention of Serious Adverse Events following Angiography - PRESERVE Study). Studija PRESERVE je randomizirana, dvostrukoslijepa, multicentrična studija usporedbe izotonične otopine bikarbonata naspram izotonične otopine natrijevog klorida i oralnog $\mathrm{N}$-acetilcisteina naspram oralnog placeba u prevenciji teških neželjenih događaja u vezi s kontrastnom nefropatijom u pacijenata $u$ kojih je učinjena koronarna ili nekoronarna angiografija. Studija je uključila 8.680 pacijenata, vrijeme praćenja bit će najmanje 3 godine, a prvi rezultati očekuju se krajem 2017. godine.

\section{ZAKLJUČAK}

Medicina temeljena na dokazima, odnosno medicina temeljena na dostupnim nam dokazima, počinje se sve više primjenjivati $u$ nefrologiji. Nefrologija je jedna od najaktivnijih grana medicine (s nažalost sve većim brojem incidentnih i prevalentnih kroničnih pacijenata), čiji se novi zamah razvoja (nakon tehnološkog preduvjeta) očekuje u stručnom i znanstvenom području u nadolazećim godinama. Tu je velika uloga nefrološke Cochrane grupe i međunarodnih nefroloških udruženja koji su se ujedinili u cilju unaprjeđenja struke, učinili veliku bazu dosadašnjih istraživanja, kritički sagledali postojeće dokaze i postavili jasna pravila po kojima bi se kontrolirane randomizirane kliničke studije trebale izvoditi u području nefrologije, koje će nam onda dati točne i precizne odgovore na sve važne aspekte naše struke. Na kraju, može se zaključiti kako se nefrološka struka ujedinila s ciljem neophodno potrebnog napretka, samokritički sagledala sve postojeće (ne)dokaze u svojoj kliničkoj znanosti, prošla svoju katarzu i postavila zdrave temelje za sve buduće naraštaje.

Izjava o sukobu interesa: autori izjavljuju da ne postoji sukob interesa.

\section{LITERATURA}

1. Lowrie EG, Laird NM, Parker TF, Sargent JA. Effect of hemodialysis on patient morbidity. Report from the National Cooperative Dialysis Study. N Engl J Med 1981;305: $1176-81$.
2. Coresh J, Selvin E, Stevens LA, Manzi J, Kusek JW, Eggers $P$ et al. Prevalence of chronic kidney disease in the United States. JAMA 2007;298:2038-47.

3. Zhang QL, Rothenbacher D. Prevalence of chronic kidney disease in population-based studies: systematic review. BMC Public Health 2008;8:117.

4. Klahr S, Levey AS, Beck GJ, Caggiula AW, Hunsickwer L, Kusek JW et al. The effects of dietary protein restriction and blood-pressure control on the progression of chronic renal disease. N Engl J Med 1994;330:877-84.

5. Strippoli GFM, Craig JC, Schena FP. The number, quality and coverage of randomized controlled trials in nephrology. J Am Soc Nephrol 2004;15:411-9.

6. Phrommintikul S, Haas SJ, Elsik M, Krum H. Mortality and target haemoglobin concentrations in anaemic patients with chronic kidney disease treated with erythropoietin: a metaanalysis. Lancet 2007;369:381-8.

7. Deo A, Schmid CH, Earley A, Lau J, Uhlig L. Loss to analysis in randomized controlled trials in CKD. Am J Kidney Dis 2011;58:349-55.

8. Inrig JK, Califf RM, Tasneem A, Vegunta RK, Molina C, Stanifer JW et al. The Landscape of Clinical Trials in Nephrology: A systematic Review of ClinicalTrials.gov. Am J Kidney Dis 2014;63:771-80.

9. Molony DA, Craig JC (eds). Evidence-based nephrology. $1^{\text {st }}$ Edition. Oxford: Wiley-Blackwell Publications, 2008.

10. Guyatt GH, Oxman AD, Kunz R, Falck-Ytter Y, Vist GE, Liberati $A$ et al. GRADE Working Group. Going from evidence to recommendations. BMJ 2008;336:1049-51.

11. Guyatt $G H$, Oxman $A D$, Kunz R, Vist GE, Falck-Ytter $Y$, Schunemann HJ. GRADE Working Group. What is "quality of evidence" and why is it important to clinicians? BMJ 2008;336:995-8.

12. Guyatt $G H$, Oxman $A D$, Vist GE, Kunz R, Falck-Ytter $Y$, Alonso-Coello $P$ et al. GRADE Working Group. GRADE: an emerging consensus on rating quality of evidence and strength of recommendations. BMJ 2008;336: 924-6.

13. Kestenbaum B, Seliger LS. Introducing the Evidence-Based Nephrology Series. Clin J Am Soc Nephrol 2016;11: 2061.

14. Georgianos IP, Agarwal R. Pharmacotherapy of hypertension in chronic dialysis patients. Clin J Am Soc Nephrol 2016;:2062-75.

15. Baigent C, Herrington WG, Coresh J, Landray MJ, Levin A, Perkovic V et al. KDIGO Controversies Conference on Challenges in the Conduct of Clinical Trials in Nephrology Conference Participants. Kidney International 2017; 92:297-305.

16. Palmer SC, Navaneethan SD i Strippoli GFM. How to read a nephrology systematic review. Nephrology 2010; 15:158-64.

17. Bello AK, Wiebe N, Garg A i Tonelli M. Basics of Systematic Reviews and Metaanalyses for the Nephrologist. Nephron Clin Pract 2011;119:c50-61.

18. Badve SV, Palmer SC, Johnson DW i Strippoli GFM. A nephrology guide to reading and using systematic reviews of randomized trials. Nephrol Dial Transplant 2015;30:878-84.

19. The Cochrane Collaboration [Internet]. London: Cochrane. Trusted evidence. Informed decisions. Better Health [cited 2017 Sep 11]. Available at: http://www.cochrane. org/index.htm. 
20. Craig JC, Higgins G, Mitchell R. Cochrane Renal Group Report. Am J Kidney Dis 2002;40:856-60.

21. Poropat G, Giljaca V, Hauser G, Štimac D. Enteral nutrition formulations for acute pancreatitis. Cochrane Database Syst Rev 2015;3:CD010605.

22. Giljaca V, Gurusamy KS, Takwoingi Y, Higgie D, Poropat $G$, Štimac D et al. Endoscopic ultrasound versus magnetic resonance cholangiopancreatography for common bile duct stones. Cochrane Database Syst Rev 2015;2: CD011549.

23. Poropat G, Giljača V, Stimac D, Gluud C. Bile acids for primary sclerosing cholangitis. Cochrane Database Syst Rev 2011;1:CD003626.

24. Giljaca V, Poropat G, Stimac D, Gluud C. Methotrexate for primary biliary cirrhosis. Cochrane Database Syst Rev 2010;5:CD004385.

25. Poropat G, Giljaca V, Stimac D, Gluud C. Bile acids for liver-transplanted patients. Cochrane Database Syst Rev 2010;3:CD005442.

26. Giljaca V, Poropat G, Stimac D, Gluud C. Glucocorticosteroids for primary sclerosing cholangitis. Cochrane Database Syst Rev 2010;1:CD004036.

27. Kelly AM, Dwamena B, Cronin P, Bernstein SJ, Carlos RC. Metaanalysis: Effectiveness of drug for preventing con- trast-induced nephropathy. Ann Intern Med 2008;148: 284-94.

28. Pannu N, Manns B, Lee H, Tonelli M. Systematic review of the impact of $\mathrm{N}$-acetylcysteine on contrast nephropathy. Kidney International 2004;65:1366-74.

29. Bagshaw S, Ghali WA. Acetylcysteine for prevention of contrast-induced nephropathy after intravascular angiography: A systematic review and metaanalysis. BMC Medicine 2004;2:38.

30. Nallamothu BK, Shojania KG, Saint S, Hofer TP, Humes $H D$, Moscucci $M$ et al. Is Acetylcysteine effective in preventing contrast-related nephropathy? A metaanalysis. Am J Med 2004;117:938-47.

31. Zagler A, Azadpour M, Mercado C, Hennekens CH. NAcetylcysteine and contrast-induced nephropathy: A metaanalysis of 13 randomized trials. AM Heart J 2006; 151:140-5.

32. Kindey disease: improving global outcomes (KDIGO) acute kidney injury work group. KDIGO clinical practice guideline for acute kidney injury. Kidney International 2012;(Suppl.2):1-138.

33. Stacul F, Molen AJ, Reimer P, Webb JAW, Thomsen HS, Morcos SK et al. Contrast induced nephropathy: updated ESUR Contrast Media Safety Committee guidelines. Eur Radiol 2011;21:2527-41. 